NOTE

\title{
Does the midnight sun increase the feeding rate and hence the growth rate of early juvenile Arcto-Norwegian cod Gadus morhua in the Barents Sea?
}

\author{
Kristin Helle* \\ Institute of Marine Research, PO Box 1870 Nordnes, 5817 Bergen, Norway
}

\begin{abstract}
The growth rate of Arcto-Norwegian cod juveniles in the Barents Sea during their first 4 mo of life is about twice that of cod juveniles in areas farther south, such as Georges Bank and the Flemish cap. Cod larvae and juveniles in the Barents Sea experience $24 \mathrm{~h}$ of daylight and thus the larvae and juveniles may continuously search for and capture prey. The stomach contents of cod juveniles caught in July 1989 were examined to determine if there were any diurnal patterns in stomach fullness or degree of digestion. No significant diurnal trends were detected. This suggests that feeding is continuous throughout the day, which enables the Barents Sea cod larvae and juveniles to grow more quickly than do cod juveniles farther south.
\end{abstract}

KEY WORDS: Arcto-Norwegian cod - Feeding rate - Daily growth rate $\cdot$ Midnight sun

Suthers \& Sundby (1996) observed that the daily growth rate of larval and early juvenile cod was about twice as high for cod larvae and juveniles in the Barents Sea compared with those off Nova Scotia. Though water temperature is considered to be the most significant external factor influencing fish growth (Campana \& Hurley 1989, Brander 1994), prey abundance also affects growth considerably (Ellertsen et al. 1980, Laurence et al. 1981, Bailey 1989, Suthers et al. 1989). At the early larval stage, feeding and hence growth is affected by small-scale seasonal changes in turbulence (Sundby \& Fossum 1990). Genetic differences have been hypothesised to cause the differences in growth rates among cod stocks (Suthers \& Sundby 1996).

Another difference between the cod juveniles in the Barents Sea and juveniles in areas farther south is the light level. North of $70^{\circ} \mathrm{N}$ the midnight sun appears in early May and continues until early August. This gives the larvae and early juvenile cod in the Barents Sea at

·E-mail: kristin.helle@imr.no $70^{\circ} \mathrm{N}$ approximately $48 \%$ more time for visual feeding than those in areas off south-western Nova Scotia at $43^{\circ} \mathrm{N}$ (Suthers \& Sundby 1996).

Blaxter (1966) found that larval herring are visual feeders and that feeding ceases below a certain light Ievel. Ellertsen et al. (1980) found that larval cod are also visual feeders and that the light intensity threshold, above which larval cod can visually search for prey, is between 0.1 and 0.4 lux, or approximately the intensity of moonlight. Since the light level in the Barents Sea will be above 0.4 lux $24 \mathrm{~h}$ a day, early juvenile cod may feed continuously. If so, this may be the reason for the high growth rate of Arcto-Norwegian cod juveniles in the Barents Sea compared with those in areas farther south.

Arcto-Norwegian cod's main spawning grounds are around Lofoten (Fig. 1). The spawning starts in March, the main peak is in April and spawning ends in May (Ellertsen et al. 1987). The ambient temperature for the eggs during this period is 1 to $4^{\circ} \mathrm{C}$. The eggs and larvae are transported by the Atlantic current and the Norwegian coastal current north and east into the Barents Sea (Ellertsen et al. 1981, Bergstad et al. 1987). By early May the larvae and early juveniles that have drifted to areas north of $70^{\circ} \mathrm{N}$ experience $24 \mathrm{~h}$ of daylight and, therefore, light should not be a limiting factor for foraging.

Early juvenile cod were collected around the clock in July 1989 during an early juvenile fish survey in the Barents Sea. The degree of stomach fullness, the degree of digestion and the wet weight of stomach contents were determined for a total of 895 juvenile cod from 81 stations. The data were examined to detect if juvenile cod appear to feed continuously throughout the day or if there is a diurnal feeding cycle.

Materials and methods. An annual early juvenile survey was conducted by the Institute of Marine Research (IMR) in June and July along the coast of 


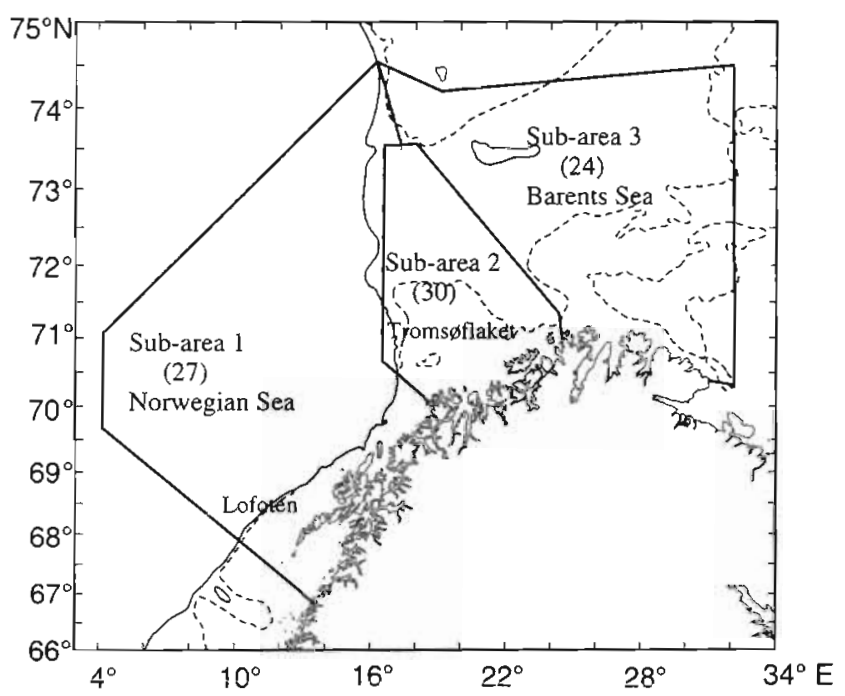

Fig. 1. The survey area and sub-areas. The numbers in parentheses are the numbers of stations where stomach samples were taken. (-) $500 \mathrm{~m}$ bottom contour, and (-.---) $300 \mathrm{~m}$ bottom contour

northern Norway and in the western Barents Sea during the years 1977 to 1991 . The main purpose of these surveys was to generate indices of abundance for early juvenile fishes with particular emphasis on early juvenile cod (in this paper defined as cod 2 to 3 mo old). In 1989, 2 vessels sampled a total of 160 stations during the period 2 to 23 July. The sampling started in the eastern part of the survey area moving westwards against the general current direction (Fig. 1). The survey region was divided into 3 sub-areas following Bjørke \& Sundby (1987); sub-area 1 is the spawning grounds around Lofoten and the Norwegian Sea, sub- area 2 is the shallow bank area, Tromsøflaket, and subarea 3 is the southwestern part of the Barents Sea. Sampling was conducted around the clock and the distance between each station was 30 nautical miles.

Juvenile fish were sampled with a midwater trawl that had a $29 \times 29 \mathrm{~m}$ opening and the cod end contained a $4 \mathrm{~m}$ liner with $5 \mathrm{~mm}$ meshes. The trawl was towed for $30 \mathrm{~min}$ at 3 depths: 40 and at $20 \mathrm{~m}$ for $7.5 \mathrm{~min}$ each and at the surface for $15 \mathrm{~min}$. Juvenile cod were counted and standard length of individuals was measured. Measurements were made on all individuals in small catches $(<50)$ or of a sub-sample if the catch was large $(>50)$. The sample was then preserved in $80 \%$ alcohol buffered with Tris (hydroxy methyl) aminometane saturated solution $\left(6.6 \mathrm{ml} \mathrm{l}^{-1}\right.$ alcohol $)$ and the alcohol was changed at the end of the survey.

Regurgitation can be a source of error for analyses of stomach contents, but due to the looped gut of gadoids, this seems to be a minor issue (Sherman et al. 1981). No regurgitated prey were found while measuring the juveniles before preservation and no prey were found in the alcohol when it was changed.

In the laboratory, the stomach and esophagus of the early juvenile cod were removed and the contents of a random sub-sample from each station (total of $895 \mathrm{cod}$ juveniles from 81 stations) were examined, both quantitatively and qualitatively. To estimate the degree of stomach fullness and digestion, standard IMR procedures (Anonymous 1990, Borge et al. 1999) were used (Table 1). The degree of stomach fullness is divided into 5 classes rating from 1 (empty) to 5 (distended) and the degree of digestion ranges from 1 (digestion not started) to 5 (digestion almost finished). Due to the subjective nature of these indices, a third method was used to quantify stomach fullness (Hyslop 1980):

Table 1. Classification of degree of stomach fullness and degree of digestion

\begin{tabular}{|c|c|c|c|}
\hline \multicolumn{2}{|l|}{ Degree of stomach fullness classification } & \multicolumn{2}{|l|}{ Degree of digestion } \\
\hline Not determined & - & Not observed & - \\
\hline $\begin{array}{l}\text { Empty } \\
\text { The stomach is empty, except maybe some } \\
\text { water }\end{array}$ & 1 & $\begin{array}{l}\text { Digestion not started } \\
\text { The content seems fresh }\end{array}$ & 1 \\
\hline $\begin{array}{l}\text { Very little content } \\
\text { So little the stomach has to be opened to dist- } \\
\text { inguish between degree of filling } 1 \text { and } 2\end{array}$ & 2 & $\begin{array}{l}\text { Digestion started } \\
\text { It is still possible to identify the species }\end{array}$ & 2 \\
\hline $\begin{array}{l}\text { Some content } \\
\text { There is external evidence that the stomach is } \\
\text { not empty }\end{array}$ & 3 & $\begin{array}{l}\text { Digestion advanced } \\
\text { The species can no longer be identified, but can be } \\
\text { divided into coarse taxa }\end{array}$ & 3 \\
\hline$\frac{\text { Full }}{\text { The stomach is full but not distended }}$ & 4 & $\begin{array}{l}\text { Digestion very advanced } \\
\text { Eyes and other identifiable prey parts can be found }\end{array}$ & 4 \\
\hline $\begin{array}{l}\text { Distended } \\
\text { The stomach is clearly expanded. The content } \\
\text { is visible on the outside }\end{array}$ & 5 & $\begin{array}{l}\text { Digestion nearly finished } \\
\text { The stomach contents are not identifiable }\end{array}$ & 5 \\
\hline
\end{tabular}




\section{$\frac{\text { Total stomach content weight }}{\text { Total fish }} \times 100$ Total fish weight}

Since the station is the primary sampling unit, the average value of an index was calculated for each station. The station averages were grouped into $2 \mathrm{~h}$ intervals (irrespective of date) and a 2 way analysis of variance (ANOVA) (Snedecor \& Cochran 1980) was used to determine if the mean (of the station averages) of the degree of stomach fullness, the degree of digestion or the index of stomach fullness, respectively, differed significantly among sub-areas or by time of day. The 3 indices are based on the same data set and thus the tests are not statistically independent, but the results will indicate if the way an index was calculated influences the conclusions.

Results. Two-way ANOVA (the model factors were 'Time' and 'Area' with Time $\times$ Area interaction terms) of the degree of digestion, degree of stomach fullness and the index of stomach fullness indicated that there were no significant interactions between time and area (all 3 p's > 0.88 ). The indices did not vary significantly over the $24 \mathrm{~h}$ period (Time effect; all p's > 0.47) nor did the indices vary significantly among the 3 sub-areas (Area effect; all p's > 0.16). In Fig. 2 are plots of the average values of the 3 indices in the entire area versus time of day along with $95 \%$ confidence intervals based on a 1-way ANOVA (factor; Time). The 1-factor ANOVA also detected no significant variation over time for the degree of digestion ( $p=0.84)$, degree of stomach fullness $(p=0.87)$ or the index of stomach fullness ( $p=0.18$ ). The estimated mean values (ignoring time) of the 3 indices in the entire area and in each sub-area are in Table 2.

Discussion. It appears that early juvenile cod in the Barents Sea (estimated mean standard length $=3.19 \mathrm{~cm}$, standard deviation $=0.52 \mathrm{~cm}$ ) feed continuously, while juvenile cod living in areas south of the Arctic Circle have a distinct diurnal feeding pattern. Grant \& Brown (1998) examined the diurnal foraging cycle for juvenile cod at a near-shore area off Newfoundland and
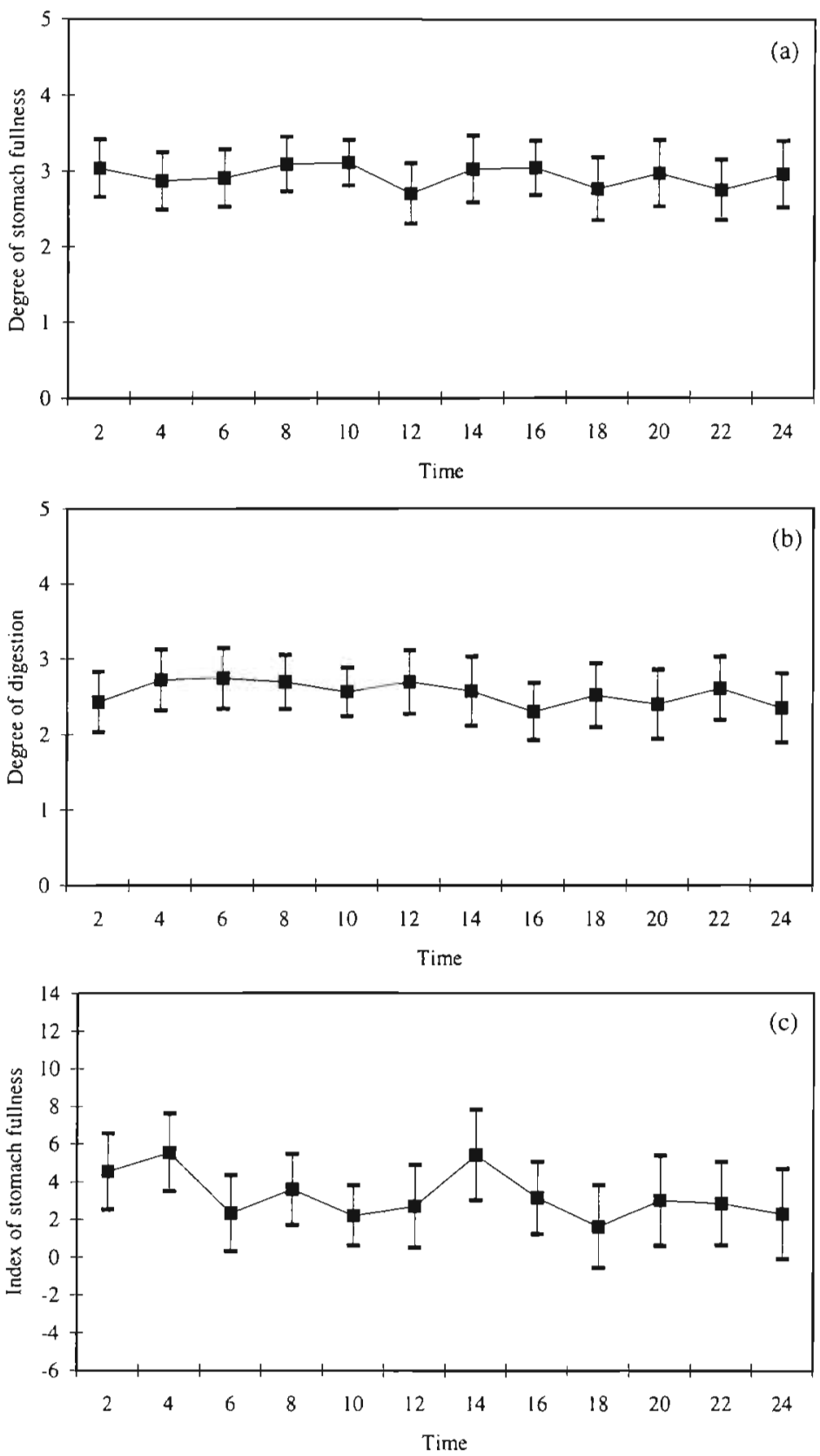

Fig. 2. Average value of (a) the degree of stomach fullness, (b) the degree of digestion, and (c) the index of stomach fullness in the entire survey area versus time of day. The bars denote $95 \%$ confidence intervals

Table 2. Estimated means of the degree of digestion, degree of stomach fullness and index of stomach fullness for the entire survey area and for the 3 sub-areas, along with their standard errors (SE)

\begin{tabular}{|lcccccccc|}
\hline & $\begin{array}{c}\text { Entire } \\
\text { area }\end{array}$ & SE & $\begin{array}{c}\text { Sub- } \\
\text { area 1 }\end{array}$ & SE & $\begin{array}{c}\text { Sub- } \\
\text { area 2 }\end{array}$ & $\begin{array}{c}\text { SE } \\
\text { Sub- }\end{array}$ & $\begin{array}{c}\text { SE } \\
\text { area 3 }\end{array}$ \\
\hline Degree of digestion & 2.57 & 0.06 & 2.59 & 0.11 & 2.70 & 0.10 & 2.34 & 0.11 \\
Degree of stomach filling & 2.95 & 0.05 & 2.98 & 0.10 & 2.85 & 0.09 & 3.07 & 0.11 \\
Index of stomach fullness & 3.18 & 0.30 & 2.73 & 0.55 & 2.78 & 0.50 & 4.31 & 0.57 \\
\hline
\end{tabular}


found a significant increase in gut fullness during the day and then a decline during the night for cod juveniles with standard length between 4.9 and $6.3 \mathrm{~cm}$. Bromley et al. (1997) examined the diurnal feeding pattern of 0-group cod in the northern North Sea and observed that 2 to $3 \mathrm{~cm}$ cod consumption peaked between 12:00 and 20:00 h, while for cod 3 to $5 \mathrm{~cm}$ in length, peak feeding was between 00:00 and 08:00 h (at the time of sampling the sunset was about 22:00 h and sunrise was at 04:00 h). For cod 3 to $5 \mathrm{~cm}$ in length, the timing of peak feeding is consistent with observations by Robb (1981).

Temperature is considered to be the dominant factor affecting the growth and condition of cod larvae caught in the open ocean (Campana \& Hurley 1989, Brander 1994). Rearing experiments show that after 5 wh the weight of larval cod reared at $10^{\circ} \mathrm{C}$ is approximately twice that of cod reared at 4 or $7^{\circ} \mathrm{C}$ (Laurence 1978).

Since a high inflow of warm Atlantic water and the abundance of zooplankton in the Barents Sea appear to be linked (Skjoldal et al. 1987, Skjoldal \& Rey 1989, Helle \& Pennington 1999), temperature may be a proxy for enhanced growth. Prey abundance can have a demonstrable effect on the growth and condition of cod larvae in the open ocean (Koslow et al. 1985, Bailey 1989, Karakiri et al. 1989, Suthers et al. 1989 , Suthers \& Sundby 1993). Laurence et al. (1981) showed that after $5 \mathrm{wk}$ the body weight of larval cod increased 7 -fold when reared at food densities of 3000 versus 500 copepods $\mathrm{l}^{-1}$ and hence varying food abundance may influence the growth of juvenile cod in the field considerably. Helle \& Pennington (1999) examined the correlation of zooplankton abundance, temperature and wind-driven water flux with the daily growth rate during the period 1978 to 1984 and found that growth appeared to be more highly correlated with zooplankton abundance and short-term water flux than with temperature.

The daily growth rates of larval and juvenile cod in the Barents Sea at about $70^{\circ} \mathrm{N}$ are much higher than those for larval and juvenile cod in areas farther south (Anderson et al. 1995). Suthers \& Sundby (1996) determined that in May to early August Arcto-Norwegian cod grow approximately twice as fast as juvenile cod off Nova Scotia. The temperature during the sampling period ranged from 6.3 to $9.8^{\circ} \mathrm{C}$ in the Barents Sea and 3.3 to $8.2^{\circ} \mathrm{C}$ for the areas off Nova Scotia. From early May to early August the Barents Sea receives about $48 \%$ more daylight than regions off Nova Scotia.

The hypothesis that longer days enhance the growth of larval and juvenile cod in the sea is supported by laboratory experiments. Cod larvae and juveniles grew more quickly when reared under conditions of continuous artificial light than under a daily cycle of
$16 \mathrm{~h}$ light: 8 h dark (Folkvord 1991, Folkvord \& Otterå 1993). However, even with $24 \mathrm{~h}$ of daylight, the growth rate of early juvenile cod in the Barents Sea varies considerable from year to year. Loeng et al. (1995) found that the daily growth rate varied from 0.58 to $1.08 \mathrm{~mm}$ $\mathrm{d}^{-1}$ during the period 1977 to 1991 .

The estimated mean degree of stomach filling was uniform (average $=2.95, \mathrm{SE}=0.05$ ) and relatively high in the entire survey region and in the 3 sub-areas (Table 2). The degree of digestion was also uniform (average $=2.57, \mathrm{SE}=0.06$ ) and it was, for the most part, possible to identify the prey. The relatively uniform amount of fresh prey in the stomachs of the early juvenile cod supports the hypotheses that early juvenile cod in the Barents Sea can and do eat $24 \mathrm{~h}$ a day, which is possibly the reason that the growth rate of juvenile cod in the Barents Sea is greater than the growth rate of juvenile cod inhabiting areas farther south.

Acknowledgements. I would like to thank Odd Nakken, Michael Pennington and 4 anonymous referees for valuable comments and suggestions.

\section{LITERATURE CITED}

Anderson JT, Dalley EL, Carscadden JE (1995) Abundance and distribution of pelagic 0-group cod (Gadus morhua) in Newfoundland waters: inshore versus offshore. Can J Fish Aquat Sci 52:115-125

Anonymous (1990) Instruks for prøvetaking og koding av fiskedata, versjon 2.0. Internt dokument, Havforskningsinstituttet, Bergen

Bailey KM (1989) Interaction between the vertical distribution of juvenile walleye pollock Theragra chalcogramma in the eastern Bering Sea, and cannibalism. Mar Ecol Prog Ser 53:205-213

Bergstad OA, Jørgensen T, Dragesund O (1987) Life history and ecology of the gadoid resources of the Barents Sea. Fish Res 5:119-161

Bjørke $H$, Sundby $S$ (1987) Distribution and abundance indices of postlarval and 0-group cod. In: Loeng $\mathrm{H}$ (ed) The effect of oceanographic conditions on distribution and population dynamics of commercial fish stocks in the Barents sea. Proceedings of the third Soviet-Norwegian symposium, Murmansk, 26-28 May 1986, Institute of Marine Research, Bergen, p 127-144

Blaxter JHS (1966) The effect of light intensity on the feeding ecology of herring. In: Bainbridge R, Evans GC, Rackham $O$ (eds) Light as an ecological factor. The British Ecological Society Symp, Vol 6. Blackwell Scientific Publications, Oxford, p 393-409

Borge A, Fotland $\AA$, Gjøsæter H, Mjanger H (1999) Manual for sampling of fish and crustaceans. Institute of Marine Research, Bergen

Brander KM (1994) Patterns of distribution, spawning, and growth in North Atlantic cod: the utility of interregional comparisons. ICES Mar Sci Symp 198:406-413

Bromley PJ, Watson T, Hislop JRG (1997) Diel feeding patterns and the development of food webs in pelagic 0 group cod (Gadus morhua L.), haddock (Melanogrammus aeglefinus L.), whiting (Merlangius merlangus L.), saithe (Pollachius virens L.), and Norway pout (Trisopterus 
esmarkii Nilsson) in the northern North Sea. ICES J Mar Sci 54:846-853

Campana SE, Hurley PCF (1989) An age- and temperaturemediated growth model for cod (Gadus morhua) and haddock (Melanogrammus aeglefinus) larvae in the Gulf of Maine. Can J Fish Aquat Sci 46:603-613

Ellertsen $B$, Solemdal $P$, Strømme $T$, Tilseth, $S$, Westgård $T$ (1980) Some biological aspects of cod larvae (Gadus morhua L.). Fiskerdir Skr Ser Havunders 17:29-47

Ellertsen B, Solemdal P, Strømme T, Sundby S, Tilseth S, Westgård T, Oiestad V (1981) Spawning period, transport and dispersal of eggs from the spawning area of ArctoNorwegian cod (Gadus morhua L.). Rapp PV Réun Cons Int Explor Mer 178:260-267

Ellertsen B, Fossum P, Solemdal P, Sundby S, Tilseth S (1987) The effect of biological and physical factors on the survival of Arcto-Norwegian cod and the influence on recruitment variability. In: Loeng $\mathrm{H}$ (ed) The effect of oceanographic conditions on distribution and population dynamics of commercial fish stocks in the Barents sea. Proceedings of the third Soviet-Norwegian symposium, Murmansk, 26-28 May 1986, Institute of Marine Research, Bergen, p $101-126$

Folkvord A (1991) Growth and cannibalism of cod juveniles (Gadus morhua): effects of feed type, starvation and fish size. Aquaculture 97:41-59

Folkvord A, Otterå H (1993) Effects of initial size distribution, day length, and feeding frequency on growth, survival, and cannibalism in juvenile Atlantic cod (Gadus morhua L.). Aquaculture 114: 243-260

Grant SM, Brown JA (1998) Diel foraging cycles and interactions among juvenile Atlantic cod (Gadus morhua) at a neashore site in Newfoundland. Can J Fish Aquat Sci 55: $1307-1316$

Helle K, Pennington M (1999) The relation of the spatial distribution of early juvenile cod (Gadus morhua L.) in the Barents Sea to zooplankton density and water flux during the period 1978-1984. ICES J Mar Sci 56:15-27

Hyslop EJ (1980) Stomach contents analysis - a review of methods and their application. J Fish Biol 17:411-429

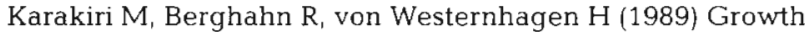
differences in 0-group place Pleuronectes platessa as revealed by otolith microstructure analyses. Mar Ecol Prog Ser 55:15-22

Koslow JA, Brault S, Dugas J, Fournier RO, Hughes P (1985) Condition of larval cod (Gadus morhua) off southwest Nova Scotia in 1983 in relation to plankton abundance and temperature. Mar Biol 86:113-121

Laurence GC (1978) Comparative growth, respiration, and delayed feeding abilities of larval cod (Gadus morhua) and

Editorial responsibility: Otto Kinne (Editor), Oldendorf/Luhe, Germany haddock (Melanogrammus aeglefinus) as influenced by temperature during laboratory studies. Mar Biol 50:1-7

Laurence GC, Smigielski AS, Halavik AT, Burns BR (1981) Implications of direct competition between larval cod (Gadus morhua) and haddock (Melanogrammus aeglefi$n u s)$ in laboratory growth and survival studies at different food densities. Rapp PV Réun Explor Mer 178:304-311

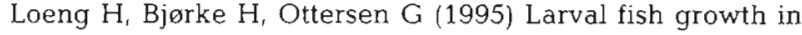
the Barents sea. In: Beamish RJ (ed) Climate change and northern fish populations. Can Spec Publ Fish Aquat Sci 121:691-998

Robb AP (1981) Observations on the food and diel feeding behaviour of pelagic 0-group gadoids in the northern North Sea. J Fish Biol 18: 183-194

Sherman K, Maurer R, Byron R, Green J (1981) Relationship between larval fish communities and zooplankton prey species in an offshore spawning ground. Rapp PV Réun Cons Int Explor Mer 178: 289-294

Skjoldal HR, Rey F (1989) Pelagic production and variability of the Barents Sea ecosystem. In: Sherman $K$, Alexander LM (eds) Biomass yields and geography of large marine ecosystems. AAAS Selected Symposium, III. Westview Press for the American Association for the Advancement of Science, Washington, DC, p 214-286

Skjoldal HR, Hassel A, Rey F, Loeng H (1987) Spring phytoplankton development and zooplankton reproduction in the central Barents Sea in the period 1979-1984. In: Loeng $\mathrm{H}$ (ed) The effect of oceanographic conditions on distribution and population dynamics of commercial fish stocks in the Barents sea. Proceedings of the third Soviet-Norwegian symposium, Murmansk, 26-28 May 1986, Institute of Marine Research, Bergen, p 59-89

Snedecor GW, Cochran WG (1980) Statistical methods, 7th edn. Iowa State University Press, Ames, Iowa

Sundby S, Fossum P (1990) Feeding conditions of Arcto-Norwegian cod larvae compared to the Rotschild-Osborn theory on small-scale turbulence and plankton contact rates. J Plankton Res 12(6):1153-1162

Suthers IM, Sundby S (1993) Dispersal and growth of pelagic juvenile Arcto-Norwegian cod (Gadus morhua), inferred from otolith microstructure and water temperature. ICES $J$ Mar Sci 50:261-270

Suthers IM, Sundby S (1996) Role of the midnight sun: comparative growth of pelagic juvenile cod (Gadus morhua) from the Arcto-Norwegian and a Nova Scotian stock. ICES J Mar Sci 53: 827-836

Suthers IM, Frank KT, Campana SC (1989) Spatial comparison of recent growth in post-larval cod (Gadus morhua) off southwestern Nova Scotia: inferior growth in a presumed nursery area. Can J Fish Aquat Sci 46(Suppl 1):13-124

Submitted: January 3, 2000; Accepted: March 24, 2000

Proofs received from author(s): April 19, 2000 